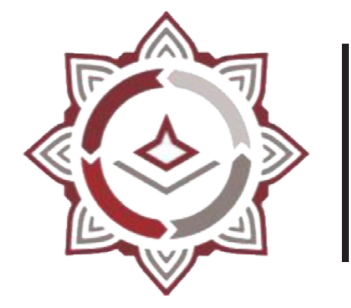

BISNIS: Jurnal Bisnis dan Manajemen Islam

P-ISSN: 2442-3718, E-ISSN: 2477-5533

Volume 9, Nomor 1, Juni 2021 (PP : 69-86)

https://journal.iainkudus.ac.id/index.php/Bisnis/index

http://dx.doi.org/10.21043/bisnis.v9i1.10350

\title{
The Effect of Product Quality and Service Quality on Consumer Satisfaction at Roya Café Mantingan
}

\author{
Hamidah Tussifah ${ }^{1}$, Nadila Princess Navitsha ${ }^{2}$ \\ University of Darussalam Gontor ${ }^{1}$, University of Darussalam Gontor ${ }^{2}$ \\ hamidatusifa78@gmail.com¹, nadilaputrinavitsha@gmail.com2
}

\begin{abstract}
Quality assurance becomes the main priority for the company. The quality of the product is closely related to the ability of the product to carry out its functions, with the good quality of the product will make the consumers satisfied and trust. Customer satisfaction is something that needs to be considered by the company. Another factor that can affect customer satisfaction is the quality of service as an effort to fulfill the needs and desires of consumers and the provision of delivery in keeping up with consumer expectations. This study aims to determine the influence of product quality and service quality partially and simultaneously on customer satisfaction at Roya Café. The research method uses a type of quantitative research. Data collection techniques are carried out by observation. The research instrument uses questionnaires distributed to Roya Café consumers. The sample was taken by 226 respondents, using Non-Probability Sampling technique with Incidental Sampling approach. The analysis techniques in this study used multiple linear regressions. The results showed that partially the quality of the product had a positive and significant effect on customer satisfaction and the quality of service partially influenced positively and significantly to customer satisfaction at Roya Café.
\end{abstract}

Keywords: Product Quality, Service Quality, Customer Satisfaction, Roya Café.

\section{Introduction}

The large population has an important impact on the lives of Indonesians. One of the important impacts is the fulfillment of food needs to meet the consumption of the population. The Association of Indonesian Jasaboga Companies (APJI) contributed to the growth of the food and beverage industry. Sektor food and beverages were able to contribute the highest with growth of $12.7 \%$ in 2018. (Trihendrawan, 2019) 
Theneed for food and beverageindustry will continue to increase and companies are required to meet, offsetting the changes that occur.

Humans have primary needs. One of the primary human needs is food and drink. Human life will be threatened if they do not eat and drink for a certain period of time. In Islamic teachings, food and drink consumed by people, especially Muslims are not free but must be selective, i.e. halal according to the guidance of Allah in the Qur'an. The Word of Allah SWT in QS. Al-Baqarah verse 168:

"O mankind, eat of what is lawful and good from what is on the earth, and do not follow the footsteps of Satan. Satan is a clear enemy to you." (QS) AlBaqarah: 168.

In addition, in sura Al-Maidah verse 88 Allah SWT said:

"And eat of what Allah has given you as lawful and good provision, and fear Allah in whom you believe." (QS) Al-Maidah: 88

From these two verses, food and drink that can be eaten by Muslims are those that meet two conditions, namely halal which means it is permissible to eat and not prohibited by sharia law, and good or thayyib which means that food is nutritious and beneficial for health.

Creativity in the culinary field must continue to develop with various innovations. Innovation in the development of food and beverage products in terms of variants, taste and food safety, innovation in human resource expertise obtained through education and training, One way to win persaingan is that companies must be able to provide satisfactionto consumers, for example by providing products of better quality, and better service than competitors, this will cause consumers to be more satisfied.

Product is one of the mostimportant for the companybecause if there is no product, the company will not be able to do anything from its business. Consumers will buy the product if interested and feel suitable, therefore the product must be adjusted to the wants and needs of consumers in order for product marketing to be successful. In other sense, the manufacture of products is better oriented to market desires or consumer tastes. (Hayati \& Sekartaji, 2015: 49-56) 
Quality assurance becomes the main priority for the company. Product quality is closely related to the product's ability to perform its functions, including overall product, reliability, accuracy, ease of operation and repair, other valuable attributes. (Setyo, 2017: 755-764) With good product quality will make consumers satisfied and trust. Customer satisfaction is something that needs to be considered by the company. Customer satisfaction is a level where the needs, wants and expectations of customers can be met which will result in a repurchase or continued loyalty. (Husna, 2018)

Islam teaches if you want to give good business results in the form of goods and services should provide quality, do not give bad or unqualified to others. Good bad business behavior of entrepreneurs determine the success and failure of the business run. The Word of Allah SWT in QS. Al Imran [3]: 159, namely:

It means: "It was by the mercy of Allah that you were gentle with them. If you had been harsh-hearted, they would have kept away from you. Therefore, forgive them: ask forgiveness for them, and consult with them in the matter. Then when you have made a determination, put your trust in Allah. God loves those who put their trust in Him."

Another factor that can affect customer satisfaction is the quality of service as an effort to fulfill the needs and desires of consumers and the provision of delivery in keeping up with consumer expectations. Good service can determine customer satisfaction is the quality of services, namely: physical evidence (Tangible),reliability (Reliability), responsiveness (Responsiveness), assurance (Assurance) and empathy (Empathy). (Apriyani \& Sunarti, 2017: 1-7) If yang consumers want fulfilled then consumers will be more satisfied. Companiesmust have a strategy to improve the quality of products, and the quality of service so that consumers continue to buy products continuously. Continuous purchase means that consumers have loyalty to the product.

Roya is one of the modern cottage business units darussalam gontor located outside the cottage to meet the needs of the cottage community and its surroundings. The resulting revenue will be deposited to the central gontor administration to be replayed for the benefit of the ummah, such as the construction of huts, and the development of cottage business units. Over time, Roya developed several business branches such as Roya Mart 1 and Roya Mart 2, Roya Kantin, Roya Café, Dan Roya Bakso. 
Roya Cafe is one of the business units of Pondok Modern Darussalam Gontor which sells food and beverages under the auspices of Latansa Roya, established on 1 Sya'ban $1441 \mathrm{H}$ to coincide with March 26, 2020. By seeing the huge potential of students and often buying food and drinks, the company strives to meet the demand by providing a place to eat that is strategically located close to campus.

At the beginning of the establishment of the product presented Roya café has a quality of delicious taste and appetizing. To meet the needs of consumers, roya café innovates products by creating other menu variations. But the taste given roya café is decreasing with the presence of new products. This is evidenced by the amount of revenue that increased by $24 \%$ in April when the products presented only 3 kinds of products. In May the amount of revenue decreased by $40 \%$ from the previous month. Then there was a fluctuation in value until finally in October the amount of revenue only increased by $3 \%$ from the first month of roya café stand that is from March.

In terms of service, roya café always innovates in designing the interior of the café, this is evidenced when the beginning of the establishment of roya café only provides a place to receive orders, after 3 months roya café began to renovate the place to meet the comfort of consumers. By providing more and more seating, fans and reading books. At this time Roya café also provides delivery services for consumers without the need to come directly to the place.

Despite the improvement in terms of service, not with the quality of the products presented. Consumers are satisfied with the service provided but not so with the quality of the products presented, this causes visitors roya café is decreasing from the beginning of its establishment.

Based on the background that has been explained, researchers will discuss about "The Influence of Product Quality and Service Quality On Customer Satisfaction At Roya Café Mantingan".

\section{Problem Formulation}

Based on the background of the problems above, it can be seen from the formulation of the problems in this study are:

1. Does product quality affect customer satisfaction at Roya Café Mantingan? 
2. Does service quality affect customer satisfaction at Roya Café Mantingan?

3. Is product quality and service quality simultaneously on customer satisfaction at Roya Café Mantingan?

\section{Research Objectives}

The objectives of this study are:

1. Knowing the influence of product quality on customer satisfaction at Roya Café Mantingan.

2. Knowing the influence of quality of service on customer satisfaction at Roya Café Mantingan.

3. Knowing simultaneously the influence of product quality and service quality on customer satisfaction at Roya Café Mantingan.

\section{Benefits of Research}

1. For the Company

As inputs and consideration materials that are useful for Roya Cafe in carrying out a good marketing strategy, especially regarding product quality, quality of service and customer satisfaction.

2. For Universities

As a library and reference for students who do research with similar problems and for further research in the future.

3. For Writers

To add insight and experience with what has been learned in college and to know the quality of products, quality of service and customer satisfaction at Roya Cafe.

\section{LITERATURE REVIEW}

\section{Product Quality}

The American Society for Quality defines quality as a characteristic of a product or service that relies on its ability to satisfy the stated or implied needs of consumers. (Kotler \& Amstrong, 2006: 273)Products are defined as everything that canbe offered to consumers and owned by consumers to meet the fullness and can satisfy 
the desires of consumers. (Amalia \& Zaenal, 2017:84) Halal products are products that come from and are processed from halal materials according to Islamic law, products that are still in the form of raw materials must be ensured to be dzatnya, and processed properly in accordance with Islamic teachings. (Amalia \& Zaenal, 2017:103) In Islamic teachings, halal products are very much a provision, namely halal because of its dzat and halal way of obtaining it. (Amalia \& Zaenal, 2017:104)

Product quality is defined as the ability of a product that can provide or performance that can satisfy the wants and needs of consumers. (Diza, Moniharapon, \& Ogi, 2016: 109-119) Product quality as a key factor that affects customer satisfaction and that can be used to measure customer satisfaction. (Kabare, Mwangi, \& Wanjau, 2019: 36-49)

The quality of food products can be determined through six dimensions, including:(Jienardy, 2017: 703-710)

1. Taste Quality. The quality of taste is maintained well according to the taste desired by consumers. (Hanisah, 2017: 1689-1699)

2. Quantity (Portion). In each serving of food has been determined the standard portion called standard portion size. Standard portion size is defined as the quantity of an item that must be served each time that item isordered. (Komala, Norisanti, \& M. Ramdan, 2019: 58-64)

3. Menu variations. Ragam types of products sold must vary with the aim of minimizing customers feel bored with the same product. (Komala et al., 2019:58-64)

4. The distinctive tastes are uniquely different and only exist in that place.

5. Hygiene hygiene. Cleanliness in the presentation of food and quality is always maintained.

6. Innovation. New cooking innovations offered make consumers do not get bored with monotonous products so that consumers have many choices. (Hanisah, 2017: 1689-1699)

\section{Quality of Service}

Service companies must maintain the quality of services offered and be greater than imagined by consumers. The Company must also understand what the needs and expectations of consumers towards the products or services offered. 
Kualitas service is the fulfillment of consumer needs based on the level of excellence of products and services in accordance with expectations so as to meet the wishes of consumers.

There are five dimensions to measure the quality of service, namely:

1. Physical Evidence. Bis similar to the appearance of physical facilities, equipment, employees, and installed materials. Describe the physical form and service that will be received by consumers. Examples include the state of the building, restaurant facilities, restaurant design, and the neatness of employee appearance. (Apriyani \& Sunarti, 2017: 1-7)

2. Reliability. Kemampuan to show that the services provided are trustworthy and accurate. (Bahar \& Sjahruddin, 2017: 14-34)

3. Areliable service is when an employee is able to provide services as promised and help solve problems faced by consumers quickly.

4. Responsiveness. Kesedian to help consumers and provide fastservice. (Bahar \& Sjahruddin, 2017: 14-34) If viewed more deeply on rapid response services can be seen from the ability of employees who quickly provide services to consumers and quickly handle their complaints

5. Guarantee. That is knowledge, polite santu, and the ability of employees to engender confidence and trust. A certainty becomes an important thing to be given to consumers, such as security and safety guarantees in transactions and guaranteed consumer confidentiality. (Apriyani \& Sunarti, 2017: 1-7)

6. Empathy. Caring and giving individual attention to consumers. Including it is to understand what consumers want

\section{Customer Satisfaction}

Customer satisfaction is a feeling of pleasure or disappointment from consumers that comes from the comparison between product performance and expectations. If the performance of the product is in accordance with the expectations of the customer's meal will feel satisfied and happy. But if the performance of the product does not meet expectations then consumers will be disappointed. (Suyanto, 2007: 10) 


\section{Dcustomer satisfaction can be divided into several kinds, namely:}

1. Hope. The ability of the company by providing adjustments to consumers for a product or service that consumers want.

2. Delivery of perceived products or services. Ability to service to consumers at the time of sale of products or services.

3. Confirm or confirm. The company's ability to meet the needs of consumers with the aim that consumers are not disappointed and satisfied with products or services in accordance with the company's promise.

4. Complaining behavior. The company's capacity to explain negative consumer feedback is positive.

\section{Research Framework}

In this study, researchers proposed two variables, namely product quality and service quality, and customer satisfaction with the research framework are as follows:

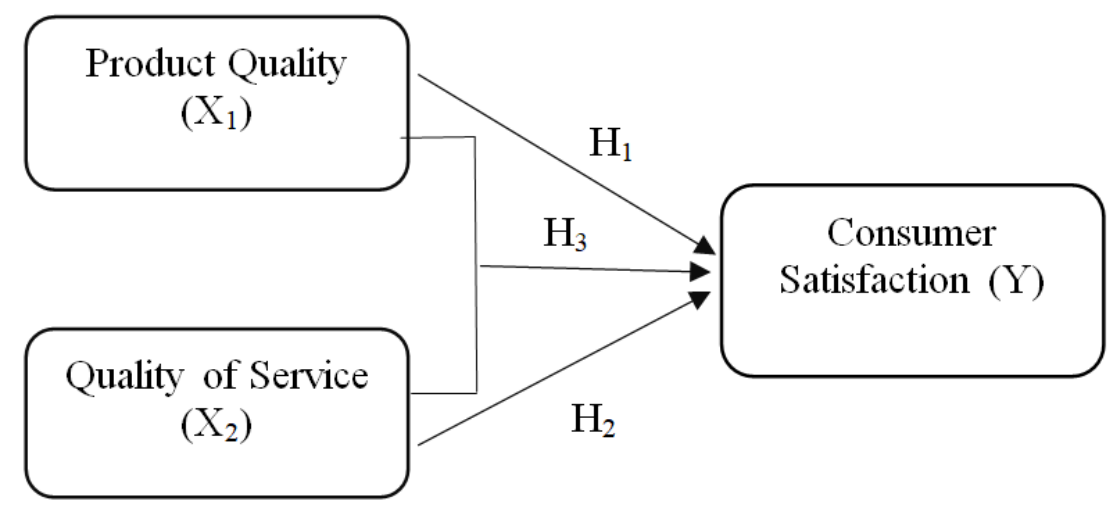

\section{Research Hypothesis}

Hypotheses are temporary answers that still have to be proven correct through research. The hypotheses in this study are:

H1: There is a positive and significant influence between product quality (X1) and customer satisfaction (Y) at Roya Cafe Mantingan.

$\mathrm{H} 2$ : There is a positive and significant influence between the quality of service (X2) to customer satisfaction (Y) at Roya Cafe Mantingan.

H3: There is a positive and significant influence between product quality (X1) 
and service quality (X2) simultaneously on customer satisfaction (Y) at Roya Cafe Mantingan.

\section{RESEARCH METHODS}

The type of research used in this study is by quantitative approach. The population in this study was Roya Cafe consumers who numbered 523 people in the last month of visitors in October 2020. Sampling techniques in this study used nonprobability sampling. The type of sample design that will be used by researchers in the form of Incidental Sampling. One of the methods used to determine the number of samples in this study is to use slovin formula, with the formula as follows:("Slovin formula," 2020)

$$
\begin{aligned}
& n=\frac{N}{1+N e^{2}} \\
& \text { Description: } \\
& \text { n= Sample Size } \\
& \mathrm{N}=\text { Population Size } \\
& \mathrm{e}=\quad \text { Allowed Error Limit of } 5 \%
\end{aligned}
$$

From the final result of the calculation above, the number of samples will be used as many as 226 respondents.

\section{Discussion}

\section{Instrument Test}

In this study based on the validity test of all indicators the question was declared valid with Corrected Item-Total Correlation $r$ count $>r$ table with a value of 0.130 . Based on reliability test of all question indicators in this study stated realible that the value of Cronbach's Alpha $>0.60$ so that it can be said that the measurement results remain consistent and can be used to process the next data. 


\section{Classic Assumption Test Results}

In research, there are several problems that often arise in multiple linear regression analysis when estimating a model with a certain amount of data that requires a classic assumption test before hypothesis testing. This test was conducted with the aim that the conclusions to be drawn do not deviate from the truth that actually occurred in the field. The classic assumption test is described as follows:

\section{Normality Test}

Normality tests were conducted through regression calculations with SPSS version 24 detected through Kolmogorov Smirnov. The results of kolmogorov Smirnov Normality test of this study are as follows:

\begin{tabular}{|c|c|c|}
\hline \multicolumn{3}{|c|}{ One-Sample Kolmogorov-Smirnov Test } \\
\hline & & Unstandardized Residual \\
\hline \multicolumn{2}{|l|}{$\mathrm{N}$} & 226 \\
\hline \multirow{3}{*}{ Normal Parameters $\mathrm{s}^{\mathrm{a}, \mathrm{b}}$} & Mean & .0000000 \\
\hline & Std. Deviation & 2.59304761 \\
\hline & Absolute & .059 \\
\hline \multirow[t]{2}{*}{ Most Extreme Differences } & Positive & .036 \\
\hline & Negative & -.059 \\
\hline \multicolumn{2}{|l|}{ Test Statistic } & .059 \\
\hline \multicolumn{2}{|l|}{ Asymp. Sig. (2-tailed) } & $.052^{\mathrm{c}}$ \\
\hline \multicolumn{3}{|l|}{ a. Test distribution is Normal. } \\
\hline \multicolumn{2}{|l|}{ b. Calculated from data. } & \\
\hline \multicolumn{3}{|c|}{ c. Lilliefors Significance Correction. } \\
\hline
\end{tabular}

Source: Primary data processed using SPSS 24, 2021

Kolmogorov Smirnov's calculations show that the significance value in product quality variables, service quality and consumer satisfaction is 0.052 greater than 0.05 , so it can be concluded that the regression model is worth using because it meets normality assumptions or normal distributed data distribution.

\section{Heteroskedisity Test}

A good regression model is what happens homoskedastisitas or that does not occur heteroskedastisitas. The results of the heteroskedastisitas test of this study are as follows: 


\begin{tabular}{|c|c|c|c|c|c|c|}
\hline \multicolumn{7}{|c|}{ Coefficients $^{\mathbf{a}}$} \\
\hline \multicolumn{2}{|c|}{ Model } & \multicolumn{2}{|c|}{$\begin{array}{l}\text { Unstandardized } \\
\text { Coefficients }\end{array}$} & \multirow{2}{*}{$\begin{array}{c}\text { Standardized } \\
\text { Coefficients } \\
\text { Beta }\end{array}$} & \multirow[t]{2}{*}{$\mathrm{t}$} & \multirow[t]{2}{*}{ Sig. } \\
\hline \multirow{4}{*}{1} & & B & Std. Error & & & \\
\hline & (Constant) & .754 & .876 & & .861 & .390 \\
\hline & Product Quality & .011 & .018 & .051 & .641 & .522 \\
\hline & Service Quality & .012 & .017 & .057 & .716 & .475 \\
\hline
\end{tabular}

a. Dependent Variable: Abs_RES

Source: Primary data processed using SPSS 24, 2021

Based on Figure 4.13 it can be concluded that the significance value (Sig.) for the product quality variable ( $(\mathrm{X} 1)$ is 0.522 . And the significance value (Sig.) for the service quality variable (X2) is 0.475 . Since the significance of the two variables above is greater than 0.05 , it is in accordance with the basis of decision-making in the glejser test, it can be concluded that there are no symptoms of heteroskedastisity in the regression model.

\section{Multicolinearity Test}

To know whether or not there is multicocity in the regression model can be seen from the VIF (Variance Inflation Factor) value and tolerance value. If the tolerance value $>0.10$ or the VIF value $<10$ then the data shows no symptoms of multicolumnity. Multicoloniality test results are as follows:

\begin{tabular}{|c|c|c|c|c|c|c|c|c|}
\hline \multicolumn{9}{|c|}{ Coefficients $^{a}$} \\
\hline \multirow{3}{*}{\multicolumn{2}{|c|}{ Model }} & \multirow{2}{*}{\multicolumn{2}{|c|}{$\begin{array}{l}\text { Unstandardized } \\
\text { Coefficients }\end{array}$}} & \multirow{3}{*}{$\begin{array}{c}\text { Standardized } \\
\text { Coefficients } \\
\text { Beta }\end{array}$} & \multirow{3}{*}{$\mathrm{t}$} & \multirow{3}{*}{ Sig. } & \multirow{2}{*}{\multicolumn{2}{|c|}{$\begin{array}{l}\text { Collinearity } \\
\text { Statistics }\end{array}$}} \\
\hline & & & & & & & & \\
\hline & & B & $\begin{array}{l}\text { Sta. } \\
\text { Error }\end{array}$ & & & & Tolerance & VIF \\
\hline \multirow{3}{*}{1} & (Constant) & 1.494 & 1.374 & & 1.087 & .278 & & \\
\hline & Product & 290 & .028 & .548 & 10.488 & .000 & .705 & 1.418 \\
\hline & $\begin{array}{l}\text { Service } \\
\text { Quality }\end{array}$ & .154 & .027 & .301 & 5.764 & .000 & .705 & 1.418 \\
\hline
\end{tabular}

a. Dependent Variable: Customer Saticfaction

Source: Primary data processed using SPSS 24, 2021

BISNIS, Vol. 9, No. I Juni 2021 
From the results of table 4.14 above can be known variance inflation factor (VIF) value on independent variable product quality $(1,418)$, variable independent service quality $(1,418)$ smaller than 10.00 and Tolerance value for each independent variable of 0.705 greater than 0.10 so it can be concluded that between independent variables there is no symptom of multicolinearity.

\section{Statistical Test}

In this study, statistical tests were conducted, namely Test F and R Coefficient of Determination (R2) with the following results:

\section{F test result table}

\begin{tabular}{|c|c|c|c|c|c|c|}
\hline \multicolumn{7}{|c|}{ ANOVA $^{\mathrm{a}}$} \\
\hline \multicolumn{2}{|c|}{ Model } & $\begin{array}{l}\text { Sum of } \\
\text { Squares }\end{array}$ & Df & Mean Square & $\mathrm{F}$ & Sig. \\
\hline \multirow{3}{*}{1} & Regression & 2008.756 & 2 & 1004.378 & 148.047 & $.000^{\mathrm{b}}$ \\
\hline & Residual & 1512.877 & 223 & 6.784 & & \\
\hline & Total & 3521.633 & 225 & & & \\
\hline
\end{tabular}

a. Dependent Variable: Customer Saticfaction

b. Predictors: (Constant), Service Quality, Product Quality

Based on the results of the analysis of test $\mathrm{F}$ on free variables (product quality and service quality) shows the value offcount 148.047 withthe value of Ftable 3.036339 this means Fcount greater than Ftable (148.047 >3.036339) with aprobability value of 0.000 which is smaller than the level of siginfikansi 0.05 . Thus on variable product quality and service quality simultaneously have a significant effect on customer satisfaction.

\section{Determination Coefficient Test Results}

\begin{tabular}{|c|c|c|c|c|}
\hline \multicolumn{5}{|c|}{ Model Summary } \\
\hline Model & $\mathrm{R}$ & R Square & Adjusted R Square & $\begin{array}{l}\text { Std. Error of the } \\
\text { Estimate }\end{array}$ \\
\hline 1 & $.755^{\mathrm{a}}$ & .570 & .567 & 2.605 \\
\hline
\end{tabular}

a. Predictors: (Constant), Service Quality, Product Quality

Source: Primary data processed using SPSS 24, 2021 
Based on table 4.19 it can be known that the value of $\mathrm{R}^{2}$ ( $\mathrm{R}$ Square) is 0.570 or equal to $57 \%$. This means that $57 \%$ of variable customer satisfaction is explained by product quality and service quality. While the remaining $43 \%$ is affected by other variables that are not included in the regression model.

\section{Multiple Linear Regression Test}

From the results of validity and reliability tests, it can be concluded that the existing data shows valid and reliable data, so that multiple linear regression analysis can be performed. This multiple linear regression equation is used to determine the influence between independent variable values-personal values consisting of product quality and service quality against dependent variable customer satisfaction. The results of multiple regression analysis can be found in the table below:

\section{Multiple Linear Regression Test Results}

\begin{tabular}{|c|c|c|c|c|c|c|}
\hline \multicolumn{7}{|c|}{ Coefficients $^{\mathrm{a}}$} \\
\hline \multirow{2}{*}{\multicolumn{2}{|c|}{ Model }} & \multicolumn{2}{|c|}{$\begin{array}{l}\text { Unstandardized } \\
\text { Coefficients }\end{array}$} & \multirow{3}{*}{$\begin{array}{c}\text { Standardized } \\
\text { Coefficients } \\
\text { Beta }\end{array}$} & \multirow[t]{2}{*}{$Q$} & \multirow[t]{2}{*}{ Sig. } \\
\hline & & $\mathrm{B}$ & Std. Error & & & \\
\hline \multirow{3}{*}{1} & (Constant) & 1.494 & 1.374 & & 1.087 & .278 \\
\hline & Product Quality & .290 & .028 & .548 & 10.488 & .000 \\
\hline & Service Quality & .154 & .027 & .301 & 5.764 & .000 \\
\hline
\end{tabular}

a. Dependent Variable: Customer Saticfaction

Based on table 4.16 hasi linear regression test can be created with the following regression equation:

$$
\begin{aligned}
& Y=1.494+0.290 X_{1}+0.154 X_{2}+e \\
& Y=\text { Customer Satisfaction } \\
& X_{1}=\text { Product Quality } \\
& X_{2}=\text { Quality of Service } \\
& e=\text { error }
\end{aligned}
$$

By using the results of the equation, the results of the analysis can be interpreted as follows: 
1. Product quality regression coefficient marked positive, meaning that every increase in one unit of product quality by 0.290 then, will increase one unit of consumer satisfaction by 0.290 ,and vice versa.

2. Coefficient of regression of service quality marked positive, meaning that every improvement of one unit of service quality of 0.154 , will increase one unit of customer satisfaction by 0.154 , and vice versa.

\section{t-Test}

Based on the results of $t$ test analysis on product quality variable significant value is 0,000 greater than 0.05 and t count of 10,488 greater than table $t 1.970563$. This indicates that there is a positive and significant influence between product quality and partial customer satisfaction. In the service quality variable can be seen that the significance value of 0.000 is smaller than 0.05 and t count is 5764 greater than table $t$ 1.970563. So it can be concluded that there is a positive and significant influence between the quality of service to partial customer satisfaction.

\section{Product Quality on Customer Satisfaction}

The results showed that partially variable product quality $\left(\mathrm{X}_{1}\right.$ has a positive and significant effect on consumer satisfaction variable (Y). Can be seen in all the results of the study used from the results of the test validity of the research instrument to hypothetical testing shows that the quality of the product affects consumer satisfaction.

In the linearity assumption test using multiple linear regression test system produced regression coefficient of 0.290 and has a positive direction, this result means that if the product quality variable is improved then the consumer satisfaction variable will increase, and vice versa, if the product quality variable decreases, then consumer satisfaction will decrease where other variables are considered unchanged or constant.

Hypothetical test results $\left(\mathrm{H}_{1}\right)$ with $\mathrm{T}$ Test have proven there is an influence between product quality variable $\left(\mathrm{X}_{1)}\right.$ and consumer satisfaction variable (Y). Through the calculation results that have been obtained, the calculated t value of 10,488 is greater than 1.970563 with a calculated significance of 0.000 is smaller than 0.05 , which means that the hypothesis in this study rejected Ho and accepted 
Ha. This test statistically proves that product quality has a positive and significant effect on consumer satisfaction.

Of all the tests that have been done means that the quality of the product greatly affects customersatisfaction. With good Product Quality will maintain and increase customer satisfaction.

The results of this study were strengthened by a study conducted by Yetty Husnul Hayati and Gracia Sekartaji (2015) with the title "The Influence of Product Quality on Customer Satisfaction In Pak Ndut Solo Duck and Fried Chicken Restaurant" which shows and states that the provision of product quality has a positive and significant influence on consumer satisfaction.

\section{Quality of Service on Customer Satisfaction}

The results showed that partially variable quality of service $\left(X_{2}\right.$ has a positive and significant effect on consumer satisfaction variable (Y). Can be seen in all the results of the study used from the results of the test validity of the research instrument to hypothetical testing shows that the quality of service affects the satisfaction of consumers en.

In the linearity assumption test using multiple linear regression test system produced regression coefficient of 0.154 and has a positive direction, this result means that if the service quality variable is improved then the customer satisfaction variable will increase, and vice versa, if the service quality variable decreases, then customer satisfaction will decrease where other variables are considered unchanged or constant.

Hypothetical test results $\left(\mathrm{H}_{2}\right.$ with $\mathrm{T}$ Test have proven there is an influence between service quality variable $\left(\mathrm{X}_{2}\right.$ ) and consumer satisfaction variable (Y). Through the calculation results that have been obtained, the calculated t value of 5,764 is greater than 1.970563 with a calculated significance of 0.000 is smaller than 0.05 , which means that the hypothesis in this study rejected Ho and accepted Ha. This test statistically proves that the quality of service has a positive and significant effect on customer satisfaction.

The quality of service is the level of excellence expected and control over the level of excellence to meet the wishes of consumers. The way to retain consumers 
is to provide services with a higher quality of service than competitors consistently and meet customer expectations. From all the tests that have been done, it can be known that there is an influence between variable quality of service to customer satisfaction at Roya Cafe Mantingan.

The results of this study were strengthened by research conducted by Rendy Gulla, Sem George Oroh, and Ferdy Roring (2015) with the title"Price Analysis, Promotion, And Quality of Service to Customer Satisfaction At Manado Grace Inn Hotel"which shows and states that the quality of service has a positive and significant influence on customer satisfaction.

\section{Effect of Product Quality And Service Quality on Customer Satisfaction}

After performing hypothetical test (H3) Test F simultaneously, attached to table 4.18 shows that variable Product Quality And Service Quality has a value of F count = 148,047 with Sig. of $=0.000$ or less than $<0.05$. This means that H3 is accepted because product quality and service quality simultaneously have a positive and significant effect on customer satisfaction roya café.

While through the examination of the coefficient of determination attached to table 4.19 obtained the result in the column Adjust R Square is 0.570 or $57 \%$. . This result contains that product quality and quality of service in explaining customer satisfaction in roya café is 57\%,while 43\%(100\% - 57\%) from consumer satisfaction comes from other factors outside the model or outside the variables of Product Quality And Quality of Service.

The results of this study were strengthened by research conducted by Yetty Husnul Hayati and Gracia Sekartaji (2015), Rendy Gulla, Sem George Oroh, and Ferdy Roring (2015) which showed and stated that the provision of Product Quality And Service Quality has a positive and significant influence on Consumer Satisfaction.

\section{CONCLUTION}

Referring to the results of the discussion that has been done, it can be concluded the following:

1. Based on the results of variable test product quality significantly affects customer satisfaction Roya Cafe, this is in accordance with previous research 
that has been done. The result of the t test shows a Sig value. 0.000. It shows that the research hypothesis that states the quality of the product partially has a significant effect on consumer satisfaction at Roya Cafe is acceptable.

2. In the results of variable test kualitas service significantly affects customer satisfaction Roya café, this is in accordance with previous research that has been done. The result of the t test shows a Sig value of 0.000 . It shows that the research hypothesis that states the quality of service partially has a significant effect on customer satisfaction in Roya Cafe is acceptable.

3. Both independent variables namely product quality and service quality have a positive and significant effect on customer satisfaction.

From the results of the study that the products offered by Roya Cafe in accordance with Islamic law and does not contain materials that violate Islamic law, as well as services provided by Roya Cafe all employees, staff are polite and friendly.

\section{Suggestions}

For further research, it should be done by deepening or developing research variables that affect consumer satisfaction because there are many factors that can affect consumer satisfaction such as price, promotion, place, brand, so as to help to expand the point of view.

\section{REFERENCE}

Amalia, D., \& Zaenal, M. (2017). Pengantar Pemasaran Islam. unida gontor press.

Apriyani, D. A., \& Sunarti. (2017). Survei pada Konsumen The Little A Coffee Shop Sidoarjo. Jurnal Administrasi Bisnis (JAB), 51(2), 1-7.

Bahar, A., \& Sjahruddin, H. (2017). Pengaruh Kualitas Produk Dan Kualitas Pelayanan Terhadap Kepuasan Konsumen Dan Minat Beli Ulang. 3, 14-34. https://doi. org/10.31227/osf.io/tc2fe

Diza, F., Moniharapon, S., \& Ogi, I. W. J. (2016). Pengaruh Kualitas Pelayanan, Kualitas Produk, dan Kepercayaan terhadap Kepuasan Konsumen (Studi Pada PT. FIFGROUP Cabang Manado). Emba, 4(1), 109-119. 
Hanisah. (2017). Kepuasan Pengunjung Terhadap Kualitas Makanan Lendot Di Kawasan Taman Kota Coastal Area Kabupaten Karimun. Dk, 53(9), 1689-1699.

Hayati, Y. H., \& Sekartaji, G. (2015). Pengaruh Kualitas Produk Terhadap Kepuasan Konsumen Di Restoran Bebek Dan Ayam Goreng Pak Ndut Solo. JIMFE (Jurnal Ilmiah Manajemen Fakultas Ekonomi), 1(1), 49-56. https://doi.org/10.34203/ jimfe.v1i1.455

Husna, N. (2018). ACHIEVE CUSTOMER SATISFACTION THROUGH EXCELLENT PUBLIC SERVICE COMMUNICATION. Retrieved from https://binus.ac.id/ malang/2018/02/achieve-customer-satisfaction-through-excellent-publicservice-communication/

Jienardy, C. (2017). Gap analisis persepsi dan ekspektasi konsumen terhadap kukalitas layanan, harga, kualitas produk esus. Jurnal Manajemen Dan Start-Up Bisnis, 1(6), 703-710.

Kabare, N., Mwangi, A. W., \& Wanjau, K. (2019). Influence of Consumer Complaints Handling On Consumer Satisfaction in Dairy Milk Processors in Kenya. International Journal of Research in Business and Social Science (2147-4478), 8(1), 36-49. https://doi.org/10.20525/ijrbs.v8i1.187

Komala, C. C., Norisanti, N., \& M. Ramdan, A. (2019). Analisis Kualitas Makanan dan Perceived Value terhadap Kepuasan Konsumen pada Industri Rumah Makan. Jurnal Riset Inspirasi Manajemen Dan Kewirausahaan, 3(2), 58-64. https://doi. org/10.35130/jrimk.v3i2.62

Kotler, P., \& Amstrong, G. (2006). Prinsip-prinsip Pemasaran. Penerbit Erlangga.

Rumus Slovin. (2020). Retrieved from https://www.rumusstatistik.com/2020/04/ rumus-slovin.html

Setyo, P. E. (2017). Pengaruh Kualitas Produk Dan Harga Terhadap Kepuasan Konsumen “Best Autoworks.” PERFORMA: Jurnal Manajemen Dan Start-Up Bisnis, 1(6), 755-764.

Suyanto, M. (2007). Marketing Strategy Top Brand Indonesia. Penerbit Andi.

Trihendrawan, N. (2019). Sektor Kuliner Indonesia Tumbuh 12,7\%. Retrieved from https://ekbis.sindonews.com/berita/1388028/34/sektor-kuliner-indonesiatumbuh-127 